Coping strategies of long-term unemployed in Portugal

Fátima Suleman

Teresa Amor

Isabel Guerra

Dezembro 2016

WP n. 0 2016/03

DOCUMENTO DE TRABALHO

WORKING PAPER 


\title{
DINAMIR'CET
}

\section{Coping strategies of long-term unemployed} in Portugal

\author{
Fátima Suleman * \\ Teresa Amor ** \\ Isabel Guerra ***
}

WP n. ${ }^{\circ} 2016 / 03$

DOI: $10.15847 /$ dinamiacet-iul.wp.2016.03

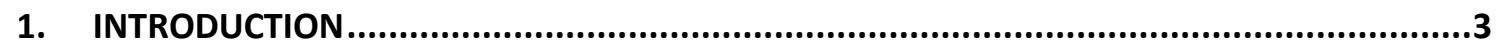

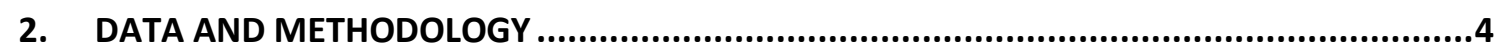

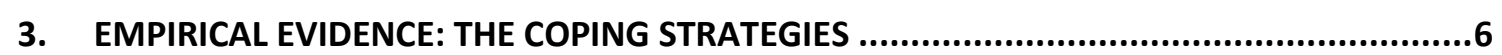

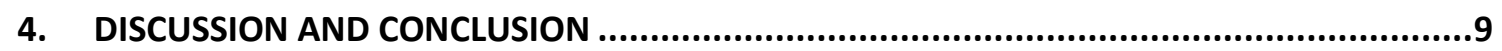

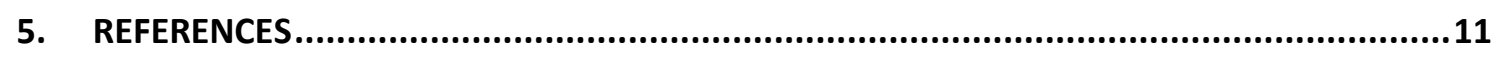

\footnotetext{
* Instituto Universitário de Lisboa (ISCTE-IUL), DINAMIA'CET - IUL, Lisboa, Portugal fatima.suleman@iscte.pt (Corresponding author).

**Instituto Universitário de Lisboa (ISCTE-IUL), DINAMIA'CET - IUL, Lisboa, Portugal - amor.teresa@gmail.com

**Instituto Universitário de Lisboa (ISCTE-IUL), DINAMIA'CET - IUL, Lisboa, Portugal imcguerra@gmail.com
} 


\title{
Coping strategies of long-term unemployed in Portugal
}

\begin{abstract}
This paper examines coping strategies adopted by women and men after job loss in Portugal. The data were gathered through interviews and an open-ended inquiry applied to fifteen unemployed persons (eight women), who were asked to describe their cognitive and behavioural efforts to cope with unemployment. Almost all the sampled unemployed persons search for a job, accept or look for training, do odd jobs, or request financial support from family and friends. However, there are interesting differences between women and men. Whereas men find the loss of their breadwinner status difficult, women worry about their economic independence and ultimately gender equality. We suggest that women's early entry in the labour market in Portugal created a social identity based on work, and this identity has contributed to negative consequences of unemployment for both genders. Men and women differ however in their emotions. Men revealed embarrassment, shame but also a colder and rational attitude, while women demonstrated strong emotions including crying during the interview. There are indeed differences in the strategies described by the people interviewed and observed by researchers. Latent strategies enhanced our understanding and therefore represented a powerful source of information.
\end{abstract}

KEYWORDS: long-term unemployment; coping strategies; gender differences; Portugal. 


\section{INTRODUCTION}

Involuntary unemployment often leads to negative life changes so that people must adopt coping strategies to deal with this stressful event. It is not just an individual problem; job loss impacts income and involves social and emotional dimensions that should be addressed by researchers and policy makers. Walch and Gordon (2008) underline the relationship between work and social identity in that individuals' self-perception is often linked to their jobs and/or work identities. This relationship makes spells of unemployment even more traumatic and a range of coping strategies must be adopted. These strategies represent the cognitive and behavioural attempts to deal with unemployment (Hanisch, 1999).

We examine the coping strategies adopted by women and men after job loss in Portugal in line with the paper by Leana and Feldman (1991) for the US. This is a timely analysis because unemployment reached a historical high of $16.9 \%$ (fourth quarter) at the peak of the crisis in 2012. The research is exploratory and based on qualitative data that examined coping strategies in different European countries. The Portuguese sample includes 15 (8 women) longterm unemployed persons who were interviewed through a standard open-ended inquiry. In short, the project asked the following question: how were unemployed persons dealing with their situation?

There is broad agreement in the literature that coping strategies can be divided into problem-focused and symptom-focused strategies (e.g. Leana and Feldman, 1991, Leana, Feldman and Tan, 1998; Hedge and Borman, 2012). Generally speaking, while problem-focused strategies imply behaviours that strive to eliminate the source of stress, symptom-focused strategies attempt to alleviate the stress without resolving the problem. Examples of problemfocused include job search, training, and geographical relocation; whereas symptom-focused strategies are characterised by requesting financial or emotional support, among others. The underlying assumption is that symptom-focused strategies eliminate symptoms of stress, namely loneliness or anxiety, but are unable to remove the source. Lattack et al. (1995) add a distinction between escape and control-focused strategies. The latter refers to proactive strategies aimed at finding a solution; avoidance or denial are escape strategies.

Despite efforts to segment coping strategies into crisp clusters, literature has pointed to two particularities. On the one hand, people adopt a variety of strategies to reduce or master stressful events (Lazarus and Folkman, 1984). On the other hand, "coping is conceptualised as oblique (overlapping) rather than orthogonal (independent)" (Lattack et al., 1995: 317). Accordingly, we suggest the unemployed simultaneously adopt different kinds of strategy. Therefore, empirical evidence would show overlapping strategies that combine emotions as well as attempts to solve the problem or proactive efforts to eliminate the source of stress.

DINÂMIA'CET - IUL, Centro de Estudos sobre a Mudança Socioeconómica e o Território

ISCTE-IUL - Av. das Forças Armadas, 1649-026 Lisboa, PORTUGAL

Tel. 210464031 - Extensão 293100 E-mail: dinamia@iscte.pt http://dinamiacet.iscte-iul.pt/ 
The literature also provides evidence that women and men differ in their behaviours to cope with job loss: men are predominantly problem-focused, while women tend to adopt symptomfocused strategies (Leana and Feldman, 1991). Kulik (2000) found that men made a more intensive job search than women; nevertheless she also reported that women face greater difficulty in finding a job. Women feel therefore discouraged by repeated failure in their job search.

Our research analyses whether this also happens in Portugal, which is a labour market traditionally characterised by a high female participation rate in both formal and informal jobs, notably one that is facing a substantial rise in the unemployment rate (from a historical low of 3.8 percent in the second quarter of 2001 to $16.9 \%$ in the fourth quarter of 2012). Furthermore, Portugal has the highest female employment rate in Southern Europe (Casaca and Damião, 2011); women entered the labour market in the 1960s in the context of colonial war and high emigration (Silva, 1983; Ferreira, 1999), and the dual-earner family is a well-established model (Tavora, 2012; Tavora and Rubery, 2013). Labour market participation empowered women in Portugal and contributed to building a female identity based on work (Silva, 1983, Ferreira, 1999, Coelho, 2010). Employment opportunities contributed consequently to financial autonomy and to improve the sense of well-being obtained from work. Therefore, the consequences of unemployment are expected to be negative for both women and men in Portugal.

\section{DATA AND METHODOLOGY}

Our empirical analysis draws on the above literature and explores the coping strategies of women and men in Portugal at the peak of the crisis in 2013. The data is from a European Project ${ }^{1}$ based on qualitative research that examined coping strategies in different countries. A sample of unemployed persons in long-term unemployment situation were interviewed through a standard open-ended inquiry and asked how they were dealing with their situation.

The data not only allows us to examine strategies used to cope with unemployment but also to unveil latent behaviours observed by interviewers during the meeting. Interviews and an open-ended inquiry were deemed the most suitable methods for the qualitative research given the variety, and often overlapping, sentiments and behaviours that characterise spells of unemployment.

Despite the proximity of problem-focused and control-focused strategies, proactivity is a key aspect of the latter. Although strategies like job search or training are indeed attempts to

\footnotetext{
${ }^{1}$ The international Project was financed by EU, DG, Employment and Social Affairs and Inclusion. It was directed by Serge Paugam. For details see Paugam (2014) entitled "Les chômeurs européens face à la crise : Enquête qualitative réalisée dans sept pays de I'Union européenne".
}

DINÂMIA'CET - IUL, Centro de Estudos sobre a Mudança Socioeconómica e o Território ISCTE-IUL - Av. das Forças Armadas, 1649-026 Lisboa, PORTUGAL

Tel. 210464031 - Extensão 293100 E-mail: dinamia@iscte.pt http://dinamiacet.iscte-iul.pt/ 
find work, self-employment or other activities during unemployment are more focused on changing the situation. Indeed, job search and training may be an active strategy or simply a response to the need to prove to the public employment services that they are trying to find a job or are willing to accept training. Consequently, three types of strategy are used to examine our data: problem, control, distinguishing between active and passive strategies, and symptom focused.

The information gathered includes the strategies reported in the literature in addition to the specificities of our sample of unemployed persons. It therefore includes strategies like odd jobs, performance of household chores, doing sports, and self-employment.

Table 1 summarises the main characteristic of unemployed people in the sample.

Table 1

Characteristics of unemployed people in the sample

\begin{tabular}{|c|c|}
\hline Variable & $\mathbf{N}$ \\
\hline Gender (Women) & 8 \\
\hline \multicolumn{2}{|l|}{ Age } \\
\hline$<35$ years & 5 \\
\hline $35-50$ years & 5 \\
\hline$>50$ years & 5 \\
\hline \multicolumn{2}{|l|}{ Unemployment duration } \\
\hline$\geq 12$ months & 15 \\
\hline$\geq 24$ months & 7 \\
\hline \multicolumn{2}{|l|}{ Entitlement to Social Benefits } \\
\hline Unemployment benefit $^{2}$ & 4 \\
\hline Social Integration Income & 6 \\
\hline Child Benefit & 5 \\
\hline \multicolumn{2}{|l|}{ Schooling years } \\
\hline$\geq 4 \leq 9$ years & 6 \\
\hline$>9 \leq 12$ years & 9 \\
\hline \multicolumn{2}{|l|}{ Cause of unemployment } \\
\hline Layoff & 14 \\
\hline \multicolumn{2}{|l|}{ Household Income in $€$ (Per capita) } \\
\hline$>631$ & 3 \\
\hline $421 / 630$ & 2 \\
\hline $211 / 420$ & 4 \\
\hline $110 / 210$ & 2 \\
\hline$<100$ & 4 \\
\hline \multicolumn{2}{|l|}{ Sources of income (Household) } \\
\hline Odd job(s) + Social benefits & 5 \\
\hline Odd job(s) + Wage (Spouse) & 3 \\
\hline Social Benefits & 6 \\
\hline Wage (other household member's wage) + Social benefits & 1 \\
\hline
\end{tabular}

2 These were the interviewees receiving unemployment benefit at the time of the interview. Six other interviewees (40\%) had previously received unemployment benefit but were no longer entitled to it.

DINÂMIA'CET - IUL, Centro de Estudos sobre a Mudança Socioeconómica e o Território ISCTE-IUL - Av. das Forças Armadas, 1649-026 Lisboa, PORTUGAL

Tel. 210464031 - Extensão 293100 E-mail: dinamia@iscte.pt http://dinamiacet.iscte-iul.pt/ 
As can be seen from Table 1, the sample have been unemployed for a long time, with low or very low income, and reduced access to social benefits or other source of income. Most of the sampled persons are women, living in cities, and almost all lost their job due to layoff.

\section{EMPIRICAL EVIDENCE: THE COPING STRATEGIES}

Table 2 distinguishes between the strategies of men and women. However, the figures reveal that some strategies are used by almost all the unemployed persons in the sample. This is the case of job search, training, doing odd jobs, and requesting financial support from family and friends.

Table 2

Comparing strategies of women and men

\begin{tabular}{l|c|c|c|c|c|c|c|c||c|c|c|c|c|c|c}
\hline Strategies & \multicolumn{7}{|c}{ Women (W) } & \multicolumn{7}{c}{ Men (M) } \\
\hline & 1 & 2 & 4 & 5 & 8 & 9 & 12 & 15 & 3 & 6 & 7 & 10 & 11 & 13 & 14 \\
\hline
\end{tabular}

Problem-focused

\begin{tabular}{l|c|c|c|c|c|c|c|c||c|c|c|c|c|c|c}
\hline Training & $\mathrm{x}$ & & & $\mathrm{x}$ & $\mathrm{x}$ & $\mathrm{x}$ & $\mathrm{x}$ & $\mathrm{x}$ & $\mathrm{x}$ & & $\mathrm{x}$ & $\mathrm{x}$ & & $\mathrm{x}$ & $\mathrm{x}$ \\
\hline Job search & $\mathrm{x}$ & $\mathrm{x}$ & $\mathrm{x}$ & $\mathrm{x}$ & $\mathrm{x}$ & $\mathrm{x}$ & $\mathrm{x}$ & $\mathrm{x}$ & $\mathrm{x}$ & $\mathrm{x}$ & $\mathrm{x}$ & $\mathrm{x}$ & $\mathrm{x}$ & $\mathrm{x}$ & $\mathrm{x}$ \\
\hline
\end{tabular}

Control-focused

\begin{tabular}{l|l|l|l|l|l|l|l|l||l|l|l|l|l|l|l}
\hline Odd jobs & $\mathrm{x}$ & $\mathrm{x}$ & $\mathrm{x}$ & & & & $\mathrm{x}$ & $\mathrm{x}$ & & $\mathrm{x}$ & & $\mathrm{x}$ & $\mathrm{x}$ \\
\hline Self- & & & & & & & & & & & & & & \\
employment & & & & $\mathrm{x}$ & & & & & & & & \\
\hline
\end{tabular}

Symptom-focused

\begin{tabular}{l|l|l|l|l|l|l|l|l||l|l|l|l|l|l}
\hline $\begin{array}{l}\text { Talking to } \\
\text { friends }\end{array}$ & $\mathrm{x}$ & & $\mathrm{x}$ & $\mathrm{x}$ & & $\mathrm{x}$ & $\mathrm{x}$ & $\mathrm{x}$ & $\mathrm{x}$ & $\mathrm{x}$ & & & & $\mathrm{x}$ \\
\hline Sports & $\mathrm{x}$ & & & & & & & $\mathrm{x}$ & & & & $\mathrm{x}$ & & \\
\hline Family or \\
friend support
\end{tabular}




\section{Coping strategies of long-term unemployed in Portugal}

There are also some additional strategies. For example, men are willing to find social assistance or engage in political action, while women are more likely to do household chores or volunteering. Although both men and women talk to their friends about the stress of job loss, it is more frequent among women.

All these strategies are similar but they have a different meaning for men and women.

Table 3 summarises the theoretical classification of the cognitive and behavioural efforts reported above and discriminates active and passive strategies.

Table 3

Specific behaviours within the three strategies

\begin{tabular}{l|c|c|c|c|c|c|c|c||c|c|c|c|c|c|c}
\hline Strategies & \multicolumn{1}{|c||}{ Women (W) } & \multicolumn{7}{c}{ Men (M) } \\
\hline & 1 & 2 & 4 & 5 & 8 & 9 & 12 & 15 & 3 & 6 & 7 & 10 & 11 & 13 & 14 \\
\hline
\end{tabular}

Problem-focused

\begin{tabular}{l|l|l|l|l|l|l|l|l||l|l|l|l|l|l|l}
\hline Training & & & & & & & & & & & & & & & \\
\hline -Active & $\mathrm{x}$ & & & $\mathrm{x}$ & & & $\mathrm{x}$ & $\mathrm{x}$ & & & & & & & $\mathrm{x}$ \\
\hline -Passive & $\mathrm{x}$ & & & & $\mathrm{x}$ & $\mathrm{x}$ & & & $\mathrm{x}$ & & $\mathrm{x}$ & $\mathrm{x}$ & & $\mathrm{x}$ & \\
\hline Job search & & & & & & & & & & & & & & & \\
\hline -Routine & & $\mathrm{x}$ & & & & $\mathrm{x}$ & & & $\mathrm{x}$ & $\mathrm{x}$ & & & & & \\
\hline -Active & $\mathrm{x}$ & & $\mathrm{x}$ & $\mathrm{x}$ & $\mathrm{x}$ & & $\mathrm{x}$ & $\mathrm{x}$ & & & $\mathrm{x}$ & $\mathrm{x}$ & $\mathrm{x}$ & $\mathrm{x}$ & $\mathrm{x}$ \\
\hline
\end{tabular}

Control-focused

\begin{tabular}{l|l|l|l|l|l|l|l|l||l|l|l|l|l|l|l}
\hline Odd jobs & & & & & & & & & & & & & & & \\
\hline -Technical & & & & & & & $\mathrm{x}$ & $\mathrm{x}$ & & $\mathrm{x}$ & & & $\mathrm{x}$ & $\mathrm{x}$ & $\mathrm{x}$ \\
\hline -Home-based & $\mathrm{x}$ & $\mathrm{x}$ & $\mathrm{x}$ & & & & $\mathrm{x}$ & & & & & & & & \\
\hline -Seasonal work & & & & & & & $\mathrm{x}$ & & & & & & $\mathrm{x}$ & $\mathrm{x}$ & $\mathrm{x}$ \\
\hline
\end{tabular}

Symptom-focused

\begin{tabular}{|c|c|c|c|c|c|c|c|c|c|c|}
\hline $\begin{array}{l}\text { Family or } \\
\text { friend sup }\end{array}$ & & & & & & & & & & \\
\hline -Money & $x$ & $x$ & $x$ & $x$ & $x$ & $x$ & $x$ & & $x$ & $x$ \\
\hline -Food & & $x$ & $x$ & $x$ & $x$ & $x$ & $x$ & $x$ & $x$ & $\mathrm{x}$ \\
\hline -Housing & & & $x$ & $x$ & $x$ & & $x$ & & & \\
\hline
\end{tabular}

People search for work in different ways; some use formal methods (public and private employment services, internet, and press), while others use informal means (networking, direct contact with firms). They have different perceptions of the job search: it may be a routine task, often to fulfil an administrative requirement; or an active pursuit of work. Furthermore, it is 
mandatory to make an active job search to gain access to unemployment insurance and benefits. One third of the sample report substantial difficulties in becoming re-employed. They persistently emphasise: "we are too young for retirement, but too old to return to the labour market". This cluster of desperate unemployed people includes especially middle-aged people who are exhausted and frustrated with their job search.

The same reasoning of active and passive strategies can be applied to training programmes: people may passively accept programmes offered by employment agencies, or make an effort to access specific training to update their skills or acquire credentials. Many of the sampled attend training offered by public employment services, while a small segment ( 2 people) seek training to further their professional development aims. It should be highlighted that training was perceived as relevant for self-employment (W5); for updating skills; and to acquire certificates to re-enter the labour market (W1, W5, W15, and M14).

Odd jobs are a recurrent strategy for coping with job loss. Almost half of the sample reports some activity that takes advantages of accumulated skills (M6, M11, W12, M13, and M14) or job opportunities in seasonal work (W12, M11, M13, and M14). Just one person had attempted to start a business (W5). As reported earlier, attempts were made to acquire entrepreneurial and self-employment skills.

Some gender bias seems to prevail in the type of odd jobs performed by the unemployed. Both men and women often make use of their technical skills when doing odd jobs, but only women go back to their traditional role in home-related activities.

The unemployed frequently request assistance from family members and friends, namely financial help, food and other goods, payment of other expenses, and housing. Indeed, some have moved back into their parents' home because their low income caused them to delay or default on the payment of mortgages or rent. Others obtain public support, namely from food bank, and churches.

However, some differences were noted between the behaviour of men and women. Men prefer to obtain charitable aid and are less likely to ask for support from their family. When this is necessary, they are more uncomfortable about doing so and it is quite often the wife or other female member that makes the request (M3, M10). Ultimately, men seem to feel more embarrassed and ashamed to ask for either private or charitable support. Although women also find this difficult, they do so in order to help their family members.

Doing sports or volunteering are less common strategies. Meanwhile, one member of the sample (M7) reports political engagement as a useful strategy to re-enter the labour market, in the belief that political party affiliation might lead to a job - "jobs for the boys". 
More importantly, some hidden strategies also warrant reflection; we label them latent strategies and they show marked distinctions between women and men. We emphasise that the information about these strategies was gathered by the researchers through observations made of the interviewees' behaviour during the meeting.

\section{DISCUSSION AND CONCLUSION}

Our results suggest that problem-focused, control-focused and symptom-focused coping strategies are not mutually exclusive. An important conclusion which can be drawn from our exploratory study is that people adopt a range of strategies to cope with unemployment and not just one kind of strategy (Lattack et al., 1995). Unemployed persons engage in a combination of the following: actively searching for a job, investing in their employability, managing their time and the routines affected by the event, and finding resources to live on.

These cognitive and behavioural efforts shed light on how the unemployed manage to deal with this stressful event that deprives them of income, and affects their identity, autonomy and self-esteem. Some of the sample reported that the spell of unemployment provided time to reflect on their identity and, more importantly, on how to use their skills and opportunities to reconstruct this identity.

We were unable to identify a sharp distinction between coping strategies by gender. We cannot corroborate the proposal of Leana and Feldman (1991) because whereas men adopt problem-focused strategies, women opt for symptom-focused strategies. Nevertheless, some underlying differences warrant further analysis.

The male breadwinner identity and other dimensions of breadwinning are affected by unemployment. In addition to expressing embarrassment and shame, the men in the sample also demonstrate a colder and rational attitude; on the other hand, the women have a stronger emotional reaction, including crying during the interview.

It is sometimes argued that unemployment is more stressful for men than for women because men associate work to well-being and find it harder to accept their partner's job and income, whereas unemployment affects less women well-being because work is less essential for them (van der Meer, 2014). We suggest that there is a fundamental difference in the way unemployment affects genders in Portugal, and this goes well beyond differences in the level of stress. The findings of our exploratory research do not allow us to conclude that unemployment is more detrimental for men than for women, but the way the genders perceive and experience unemployment is different.

The women in our sample appeared more comfortable with multiple identities, but were concerned about the prospect of economic and financial dependence. Nevertheless, they adopt a 
strategy that makes uses of household skills to deal with the loss of financial autonomy. All the women interviewed reported that gaining personal independence had always been a strong motivation for participating in the labour market. Some of them are currently trying to regain their autonomy through doing odd jobs, notably cooking and delivering home-made food, waitressing, fruit/olive harvesting, care services for the elderly, accounting services; or by trying to establish their own small business.

Latent behaviours witnessed by the interviewer undoubtedly confirmed that the gender distinctions in coping strategies went beyond finding a solution (problem-focused) versus alleviating the stress of unemployment (symptom-focused). While the men and women in the sample expressed their emotions differently, both genders had difficulty in dealing with major economic and social consequence of unemployment: the loss of income and the need to ask for support from family or friends. This is a particularly striking finding in relation to women in Portugal; indeed, the women in our sample suggested that unemployment would have a significant effect on gender equality.

Despite the methodological issues of this study, it opens the way for further research into the specific reported coping strategies and behaviours observed by researcher that distinguish men and women. The findings confirm that families play an important role in Southern European countries by providing support and/or complementing or even replacing the social protection provided by the State or charities. The research should also be extended to countries with different patterns of female participation in order to gain a fuller understanding of gender differences. In Portugal, our study showed that independence and financial autonomy are of great importance to women, notably because it is also related to their own sense of self. 


\section{REFERENCES}

CASACA, S.F., Damião, S. (2011). Gender and well-being in the labour market: gender (in)equality in the labour market and the southern European welfare states. In Addis, E., Villota, P., Degavre, F., Eriksen, J. (orgs.), Gender and Well-Being. The Role of Institutions (pp. 183199). Farnham: Ashgate.

COELHO, L. (2010). Mulheres, Família e Desigualdade em Portugal. Doutoramento em Economia na Universidade de Coimbra.

FERREIRA, V. (1999). Os Paradoxos da Situação das Mulheres em Portugal. Revista Crítica de Ciências Sociais, 52/53, 199-228.

HANISCH, K.A. (1999). Job loss and unemployment research from 1994 to 1998: a review and recommendations for research and intervention. Journal of Vocational Behavior, 55, 188-220.

HEDGE, W.C. and Borman, J.W. (2012). The Oxford Handbook of Work and Aging. NY: Oxford University Press.

KULIK, L. (2000). Jobless men and women: A comparative analysis of job search intensity, attitudes toward unemployment, and related responses. Journal of Occupational and Organisational Psychology, 73, 487-50.

LATTACK, J.C., Kinicki, A.J. and Prussia, J.E. (1995). An integrative process model of coping with job loss. Academy of Management Review 20(2), 311-342.

LAZARUS, R. S. and Folkman, S. (1984). Stress, Appraisal and Coping. New York: Springer.

LEANA, C.R. and Feldman, D.C. (1991). Gender differences in responses to unemployment. Journal of Vocational Behavior, 38, 65-77.

LEANE, C.R., Feldman, D.C. and Tan, G.Y. (1998). Predictors of coping behavior after a layoff. Journal of Organizational Behavior 19(1), 85-97.

PAUGAM, S. (2014). Les chômeurs européens face à la crise: Enquête qualitative réalisée dans sept pays de l'Union européenne. (Rapport final pour la Commission Européenne). DG Emploi, Affaires sociales et inclusion. Bruxelles.

DINÂMIA'CET - IUL, Centro de Estudos sobre a Mudança Socioeconómica e o Território ISCTE-IUL - Av. das Forças Armadas, 1649-026 Lisboa, PORTUGAL

Tel. 210464031 - Extensão 293100 E-mail: dinamia@iscte.pt http://dinamiacet.iscte-iul.pt/ 
SILVA, M. (1983). O Emprego das Mulheres em Portugal - A 'mão invisível' na discriminação sexual no emprego. Porto: Afrontamento.

TAVORA, I. (2012). The southern European social model: familialism and the high rates of female employment in Portugal. Journal of European Social Policy 22(1), 63-76.

TAVORA, I., Rubery, J. (2013). Female employment, labour market institutions and gender culture in Portugal. European Journal of Industrial Relations 19(3), 221-237.

VAN DER MEER, P. H. (2014). Gender, unemployment and subjective well-being: Why being unemployed is worse for men than for women. Social Indicators Research, 115(1), 23 - 44.

WALCH, K. and Gordon, J. (2008). Creating an individual work identity. Cornell University:http://scholarship.sha.cornell.edu/articles/582 